Check for updates

The BMJ

Cite this as: BMJ 2021;373:n1274 http://dx.doi.org/10.1136/bmi.n1274 Published: 18 May 2021

\title{
Covid-19: Most UK adults had antibodies after one dose of AstraZeneca or Pfizer vaccine, data suggest
}

\section{Gareth lacobucci}

More than nine in 10 UK adults have antibodies to SARS-CoV-2 following one dose of the Oxford AstraZeneca or Pfizer BioNTech vaccine, while almost everyone does after a second dose, preliminary data suggest.

A study of 8517 adults in England and Wales by University College London's Virus Watch project found that $96.42 \%$ (95\% confidence interval 96 to 96.79) of people who had either vaccine had developed antibodies 28 to 34 days after their first dose, rising to $99.08 \%$ (95\% CI 97.8 to 99.62 ) within seven to 14 days of the second dose.

Seropositivity rates and spike antibody levels rose more quickly following the first dose of the Pfizer vaccine (89.27\% (95\% CI 83.52 to 93.25) than for AstraZeneca (66.27\% (95\% CI 2.56 to 69.80 ) at 14 to 20 days, but were equivalent for both vaccines by 4 weeks ( $96.17 \%$ (95\% CI 94.22 to 97.50) v 95.21\% (95\% CI 93.75 to 96.35)).

"Our data indicate very high rates of seroconversion to spike following a single dose of either vaccine, with near complete seroconversion following a second dose, in people with no evidence of prior infection," said the UCL research team led by Maddie Shrotri.

The study, published as a preprint and currently undergoing peer review, examined 13232 antibody samples taken from the 8517 study participants (8115 following AstraZeneca and 5008 following Pfizer) with an average age of 65 (interquartile range 58 to 71).

Participants provided blood samples and self-reported vaccination status. None had antibodies before receiving a first dose.

After a single dose, there was evidence to suggest a significant difference in antibody levels by age group at $\geq 28$ days $(\mathrm{P}=0.0001)$, with levels lower in older people (18 to $34 \mathrm{y}$, median $63.4 \mathrm{U} / \mathrm{ml}$ (IQR 34.2 to 99.34) $v \geq 80 y, 26.13$ (8.34 to 80.4) ( $\mathrm{P}=0.0001)$ ).

In 65 to 79 year olds who had had only one dose, lower antibody levels were observed in men $(25.9 \mathrm{v}$ 42.3 U/ml, $\mathrm{P}<0.0001$ ), people with a chronic condition (33.0 v 41.2 U/ml, $\mathrm{P}<0.0001)$, diabetes (22.32 v 36.01 $\mathrm{U} / \mathrm{ml}, \mathrm{P}<0.0001)$, cardiovascular disease $(32.1 v 36.7$ $\mathrm{U} / \mathrm{ml}, \mathrm{P}=0.0002)$, or those history of cancer (30.1 $\mathrm{v}$ $35.7 \mathrm{U} / \mathrm{ml}, \mathrm{P}=0.0001$ ), particularly those with haematological rather than solid organ cancer $(7.48$ $v 31.68 \mathrm{U} / \mathrm{ml}, \mathrm{P}<0.0001)$, and those currently on immunosuppressive therapy $(21.7 v 35.6 \mathrm{U} / \mathrm{ml}$, $\mathrm{P}<0.0001)$.

But disparities did not persist after a second dose, with high antibody titres $(\geq 250 \mathrm{O} / \mathrm{ml}$ ) observed for nearly all people across all ages, demographics, and clinical groups.

The authors concluded, "High seroconversion rates after the first dose lend support to the UK policy to prioritise first dose coverage across the population, however our data also suggest attenuated immune responses in some clinical groups, which warrant further investigation."

The Virus Watch study is being funded by UK Research and Innovation and the Department of Health and Social Care through the National Institute for Health Research.

1 Shrotri M, Fragaszy E, Geismar C, et al. Spike-antibody responses following first and second doses of ChAdOX1 and BNT162b2 vaccines by age, gender, and clinical factors - a prospective community cohort study (Virus Watch).Medrxiv 2021.05.12.21257102v2 [Preprint]. 2021www. medrxiv.org/content/10.1101/2021.05.12.21257102v2.

This article is made freely available for use in accordance with BMJ's website terms and conditions for the duration of the covid-19 pandemic or until otherwise determined by BMJ. You may use, download and print the article for any lawful, non-commercial purpose (including text and data mining) provided that all copyright notices and trade marks are retained. 